\title{
Thioalkalispira microaerophila gen. nov., sp. nov., a novel lithoautotrophic, sulfur-oxidizing bacterium from a soda lake
}

${ }^{1}$ Institute of Microbiology, Russian Academy of Sciences, Prospect 60-let Octyabrya 7/2, 117811

Moscow, Russia

${ }^{2}$ Kluyver Laboratory of Biotechnology, Delft Technical University, Julianalaan 67, 2628 BC Delft, The Netherlands

${ }^{3}$ Bioengineering Center, Russian Academy of Sciences, Prospect 60-let Octyabrya 7/1, 117811 Moscow, Russia

${ }^{4}$ Laboratory for Electron Microscopy, Biological Centre, University of Groningen, 9750 AA Haren, The Netherlands

\author{
Dimitry Yu. Sorokin, ${ }^{1,2}$ Tat'yana P. Tourova, ${ }^{1}$ Tat'yana V. Kolganova, ${ }^{3}$ \\ Klaas A. Sjollema ${ }^{4}$ and J. Gijs Kuenen ${ }^{2}$
}

Author for correspondence: Dimitry Yu. Sorokin. Tel: +7 95135 0109. Fax: + 7951356530.
e-mail: soroc@inmi.da.ru

An anaerobic enrichment medium (pH 10) with thiosulfate as electron donor and nitrate as electron acceptor was inoculated with sediment from soda lake Fazda (Wadi Natrun, Egypt); a novel strain, ALEN 1', was isolated from the subsequent enrichment culture. Cells of strain ALEN ${ }^{\top}$ had a spiral morphology (0.3-0.45 $\times 1-4 \mu \mathrm{m})$, were motile and had a single polar flagellum. Sphaeroplasts were formed by the cells and were rapidly lysed during prolonged aerobic incubation of cultures. Cells of strain ALEN $1^{\top}$ contained a membrane-associated yellow pigment. The metabolism of this novel organism was obligately chemolithoautotrophic, and thiosulfate or sulfide were utilized as electron donors. Washed cells of strain ALEN $1^{\top}$ oxidized thiosulfate, sulfide, polysulfide and elemental sulfur to sulfate. Best growth was observed when the strain was grown under micro-oxic conditions (1-2\% $\mathrm{O}_{2}$ in gas phase), whereas growth was inhibited under fully oxic conditions. Nitrate was reduced to nitrite without growth of the novel organism, but other nitrogen oxides were not utilized as electron acceptors. Strain ALEN $1^{\top}$ was alkaliphilic and moderately halophilic. It grew between pH 8 and 10.4 (optimum around pH 10) with a salt concentration of between 0.3 and $1.5 \mathrm{M} \mathrm{Na}^{+}$(optimum $0.5 \mathrm{M}$ ). The maximum growth rate $\left(0.08 \mathrm{~h}^{-1}\right)$ of the organism was achieved in a thiosulfatelimited micro-oxic continuous culture (pH 10). Phylogenetic analyses of the 16S rDNA sequences of strain ALEN $1^{\top}$ and its closest relatives demonstrated that this strain formed a deep branch within the $\gamma$-Proteobacteria, with no obvious association to any described cluster of species/genera. On the basis of its unique physiological properties and distinct phylogenetic position, it is proposed that strain ALEN $1^{\mathrm{T}}$ ( = DSM $14786^{\mathrm{T}}=$ UNICEM $212^{\mathrm{T}}$ ) represents a novel genus within the $\gamma$-Proteobacteria, for which the name Thioalkalispira is proposed. It is also proposed that the type species of this novel genus be named Thioalkalispira microaerophila.

Keywords: haloalkaliphilic, soda lake, sulfur-oxidizing bacteria, microaerophilic

\section{INTRODUCTION}

Sulfur-oxidizing bacteria (SOB) play an important role in element cycling in natural and man-made

Published online ahead of print on 28 June 2002 as DOI 10.1099/ ijs.0.02339-0.

Abbreviation: $\mathrm{SOB}$, sulfur-oxidizing bacteria.

The GenBank accession number for the 16S rDNA sequence of Thioalkalispira microaerophila ALEN $1^{\top}$ is AF481118. environments that are rich in reduced sulfur compounds (Jørgensen, 1989; Robertson \& Kuenen, 1992). Until recently, known SOB included neutrophilic and acidophilic species that grew stably between $\mathrm{pH} 2$ and 8 (Kelly, 1989; Pronk et al., 1990; Kuenen et al., 1992). However, an ongoing microbiological survey of soda lakes, unique natural haloalkaline habitats, has led to the isolation of a number of previously unidentified haloalkaliphilic SOB, which includes heterotrophic (Sorokin et al., 1996) and obligately autotrophic 
(Sorokin et al., 2000) bacterial species. Overall, more than 80 strains of haloalkaliphilic, obligately autotrophic SOB have been isolated and characterized (Sorokin et al., 2001, 2002a, b) from the soda lakes of different continents. These bacteria differ from neutrophilic species in their ability to grow optimally at $\mathrm{pH}$ values greater than 9 and up to $\mathrm{pH} 10 \cdot 5-10 \cdot 6$ in saline media strongly buffered with a sodium bicarbonate/ carbonate mixture. All of the soda-lake species characterized to date have been assigned to two recently described genera, Thioalkalimicrobium and Thioalkalivibrio, within the $\gamma$-Proteobacteria (Sorokin et al., 2001a).

With the exception of the facultatively anaerobic species Thioalkalivibrio denitrificans, which displays denitrifying activity (Sorokin et al., 2001b), all of the described haloalkaliphilic SOB are obligately aerobic. During our investigations, we have often observed fine, Spirillum-like bacterial cells in anaerobic enrichments of soda-lake-sediment samples supplemented with thiosulfate and nitrate. However, using anoxic conditions, these cells were lost during further manipulations. By shifting to micro-oxic cultivation a preferential enrichment was achieved that allowed the isolation of these cells in pure culture. In this study, the bacterium isolated in pure culture has been characterized and is proposed to represent a novel genus within the $\gamma$-Proteobacteria.

\section{METHODS}

Samples. Samples of the littoral sediments from eight hypersaline soda lakes in the Wadi Natrun, Libyan Desert, Egypt, were obtained in October 2000. The microbial composition of these unusual lakes, with particular emphasis on the anaerobic phototrophs, was described by Imhoff et al. (1979). The salt content and the $\mathrm{pH}$ of the water in the lakes varied from 220 to $360 \mathrm{~g} \mathrm{l}^{-1}$ and from $\mathrm{pH} \mathrm{9.2} \mathrm{to} 10 \cdot 3$, respectively.

Media and culture conditions. For routine cultivation of strain ALEN $1^{\mathrm{T}}$, a mineral medium strongly buffered by a sodium bicarbonate/carbonate mixture containing $0.6 \mathrm{M}$ total $\mathrm{Na}^{+}$at $\mathrm{pH} 10-10 \cdot 1$ was used as described previously (Sorokin et al., 2001a). Thiosulfate (40-80 mM) served as the electron donor and nitrate $\left(3 \mathrm{mM}\right.$ as $\left.\mathrm{KNO}_{3}\right)$ as the nitrogen source. Solid alkaline medium was prepared by 1:1 mixing of $4 \%$ agar and double-strength mineral base at $50{ }^{\circ} \mathrm{C}$. Enrichments for denitrifying SOB were performed in $100 \mathrm{ml}$ serum bottles, with butyl-rubber stoppers, filled with $50 \mathrm{ml}$ of alkaline base with $20 \mathrm{mM}$ thiosulfate and $30 \mathrm{mM}$ nitrate. Anoxic conditions were achieved by five cycles of evacuation-argon flushing with active degassing of the liquid. Micro-oxic incubation was performed in closed 3.51 jars filled with argon containing $1 \% \mathrm{O}_{2}$. The gas phase was renewed every 3 days. Anaerobic plate incubation was performed using the same jars filled with pure argon in the presence of an anaerobic catalyser (Oxoid). Growth with $\mathrm{H}_{2}$ as electron donor was tested in $100 \mathrm{ml}$ bottles, sealed with butyl-rubber stoppers, with $10 \mathrm{ml}$ medium under an atmosphere containing $98 \% \mathrm{H}_{2}$ and $2 \%$ $\mathrm{O}_{2}$. Methylotrophy was tested with methanol and formate $(5 \mathrm{mM})$ under aerobic and micro-oxic conditions.
Continuous cultivation was performed in a 1.51 laboratory fermenter ( 1.31 working volume) that was fitted with $\mathrm{pH}$ and oxygen controllers (Applicon). The $\mathrm{pH}$ was controlled by automatic titration with $2 \mathrm{M} \mathrm{NaOH}$ at $\mathrm{pH} 10-10 \cdot 05$. Air and argon were supplied to the fermenter at defined rates via a gas-controlling device; the dissolved oxygen concentration was adjusted to $0 \cdot 5-2 \%$ air saturation by changing the ratio of gases and the stirring speed. The limiting substrate was thiosulfate $(30 \mathrm{mM})$. The temperature was adjusted to $30^{\circ} \mathrm{C}$. The medium was supplied from two reservoirs that contained double-strength acid and alkali solutions, respectively, with the same final medium composition as utilized for batch cultivation. The maximum specific growth rate of strain ALEN $1^{\mathrm{T}}$ was determined experimentally as the dilution rate at which wash-out of the biomass and accumulation of thiosulfate started. The molar growth yield was calculated on the basis of the biomass protein produced per mole of substrate completely oxidized to sulfate.

To test the $\mathrm{pH}$ range for growth of strain ALEN $1^{\mathrm{T}}$, a mineral base medium was prepared based on $0 \cdot 1 \mathrm{M}$ HEPES/ $\mathrm{Na}_{2} \mathrm{CO}_{3}(\mathrm{pH} 7-8)$ with $0.6 \mathrm{M} \mathrm{NaCl}$ or based on sodium carbonate/bicarbonate $(\mathrm{pH} 8-11)$ with $0.6 \mathrm{M}$ total $\mathrm{Na}^{+}$. The $\mathrm{Na}^{+}$tolerance of the novel strain was tested in a sodium carbonate/bicarbonate-based mineral medium that contained $0 \cdot 1-2 \mathrm{M}$ total $\mathrm{Na}^{+}$at $\mathrm{pH} 10$. The same $\mathrm{pH}$ and salinity buffers were used in the experiments with washed cells.

Activity tests with washed cells. Cells of strain ALEN $1^{\mathrm{T}}$ were collected from the effluent of the micro-oxic chemostat culture that had been grown with thiosulfate at $\mathrm{pH} 10$ and were harvested by centrifugation. They were then washed and resuspended in mineral carbonate buffer $(\mathrm{pH} 10)$ to give a cell suspension of $20 \mathrm{mg}$ protein $\mathrm{ml}^{-1}$ and stored at $4{ }^{\circ} \mathrm{C}$ under an argon atmosphere to prevent lysis. The respiratory activity of the cells in the presence of different sulfur compounds was tested by using an oxygen electrode assemblage, as described previously (Sorokin et al., 2001a).

To test the ability of strain ALEN $1^{\mathrm{T}}$ to reduce nitrogen oxides, a $5 \mathrm{ml}$ suspension of cells was diluted 20 times in the anaerobic buffer ( $\mathrm{pH} \mathrm{10)}$, placed in $12 \mathrm{ml}$ serum flasks sealed with butyl-rubber stoppers and subjected to five cycles of argon flushing-evacuation with active liquid degassing. The experiments were started by injection of electron donors (thiosulfate, sulfide or polysulfide, $1-5 \mathrm{mM} ; \mathrm{H}_{2}, 100 \%$ in gas phase) and acceptors (nitrate or nitrite, $5 \mathrm{mM} ; \mathrm{N}_{2} \mathrm{O}$, $100 \%$ in gas phase) into the serum flasks.

The influence of oxygen on inorganic carbon assimilation by strain ALEN $1^{\mathrm{T}}$ was examined using $\mathrm{NaH}^{14} \mathrm{CO}_{3}$ and $0 \cdot 05 \mathrm{M}$ Tris $/ \mathrm{HCl}(\mathrm{pH}$ 9) containing $0.6 \mathrm{M} \mathrm{NaCl}$ as a buffer system. A cell suspension $\left(5 \mathrm{ml} ; 0 \cdot 05-0.15 \mathrm{mg}\right.$ protein $\left.\mathrm{ml}^{-1}\right)$ was injected into a $120 \mathrm{ml}$ serum bottle that had been sealed with a butyl-rubber stopper and filled with oxygen-free argon. Pure oxygen was added by syringe to bottles covering the range $0-20 \% \mathrm{O}_{2}$ in the gas phase. The reaction was started by the addition of $\mathrm{NaH}^{14} \mathrm{CO}_{3}\left(5 \mathrm{mM}\right.$; containing $2 \mu \mathrm{Ci}^{14} \mathrm{C}$ $\left.\mathrm{mmol}^{-1}, 74 \mathrm{kBq}^{14} \mathrm{C} \mathrm{mmol}^{-1}\right)$ and thiosulfate $(2 \mathrm{mM})$ to the bottles. The bottles were then incubated on a rotary shaker at 100 r.p.m. and $30^{\circ} \mathrm{C}$. Samples $(1 \mathrm{ml})$ were taken from the bottles by syringe at $20 \mathrm{~min}$ intervals, to determine the initial rate of carbon fixation (Sorokin et al., 2000).

Enzyme activity in a cell-free extract. A cell-free extract of strain ALEN $1^{\mathrm{T}}$ was obtained by ultrasonic treatment of cells that had been grown in continuous culture at $\mathrm{pH} 10$. The membrane fraction was separated by ultracentrifugation (Beckman) at $150000 \mathrm{~g}$ for $2 \mathrm{~h}$. 
The nitrate and nitrite reductase activities of the cell-free extract were measured using methyl viologen reduced with excess dithionite as the artificial electron donor, by analysing the formation or consumption of nitrite at $\mathrm{pH} 7-10$ using buffers containing $0.3 \mathrm{M}$ total $\mathrm{Na}^{+}$. Furthermore, nitrate and nitrite reductase activities in the cell-free extract were assayed after the proteins had been separated by SDSPAGE and activity-stained (Martinez Murillo et al., 1999). The activities of sulfur-metabolizing enzymes and of cytochrome oxidase were measured in the soluble and membrane fractions as described previously (Sorokin et al., 2000, 2001a). Catalase activity was assayed in the soluble fraction in $0.05 \mathrm{M}$ Tris $/ \mathrm{HCl}(\mathrm{pH} 8)$ using the iodimetric method for $\mathrm{H}_{2} \mathrm{O}_{2}$ detection (Sumner \& Dounce, 1955).

Absorption spectra for the cytochromes in the soluble and membrane fractions were recorded on a UV/visible diodearray HP 8453 spectrophotometer (Hewlett Packard) using an ascorbate/TMPD $\left(N, N, N^{\prime}, N^{\prime}\right.$-tetramethyl- $p$-phenylenediamine hydrochloride) mixture and solid dithionite as the reductants.

Chemical analysis. Inorganic sulfur compounds, nitrate, nitrite and protein concentrations were determined by spectrophotometric methods as described previously (Sorokin et al., 2001a, b). Sulfate was measured by ionic chromatography using a Nucleosile column $(250 \times 4 \mathrm{~mm}$; Marchery Nagel) and elution with 0.04 M sodium salycilate (pH 4) at $1 \mathrm{ml} \mathrm{min}^{-1}$, and a model 410 Refractometer (Waters) detector.

Electron microscopy. Cells were pelleted, washed with $0.6 \mathrm{M}$ $\mathrm{NaCl}(\mathrm{pH} 8)$ and immediately frozen at $-80{ }^{\circ} \mathrm{C}$; they were kept at this temperature until processed. The cells were thawed in $3 \%(\mathrm{v} / \mathrm{v})$ glutaraldehyde in $0 \cdot 1 \mathrm{M}$ cacodylate buffer ( $\mathrm{pH} 7$ ), fixed for $2 \mathrm{~h}$ on ice, washed in the same buffer, post-fixed in $1 \%(\mathrm{w} / \mathrm{v}) \mathrm{OsO}_{4}$ for $3 \mathrm{~h}$ at room temperature, washed and stained overnight with $1 \%(\mathrm{w} / \mathrm{v})$ uranylacetate, dehydrated in an ethanol series and then embedded in Epon resin. Thin-sections were stained with $1 \%(\mathrm{w} / \mathrm{v})$ lead citrate. A portion of the fixed cells was positively stained with $1 \%$ (w/v) phosphotungstic acid for total preparations.

Total DNA analysis. DNA extraction, DNA G $+\mathrm{C}$ content determination and DNA-DNA hybridization were performed according to standard protocols (Marmur, 1961; De Ley et al., 1970).

Amplification and sequencing of the 16S rRNA gene of strain ALEN $1^{\top}$. DNA was obtained by performing a standard phenol/chloroform extraction. The 16S rRNA gene was selectively amplified using primers 5'-AGAGTTTGATCCTGGCTCAG-3' (forward) and 5'-TACGGTTACCTTGTTACGACTT-3' (reverse). PCR products were purified from low-melting-point agarose by using the Wizard PCR Prep kit (Promega) according to the manufacturer's instruction. An almost-complete 16S rDNA sequence (1437 nt) was obtained by sequencing using the Promega Silver Sequencing kit (Promega) according to the manufacturer's instructions but with minor modifications.

16S rDNA sequence analysis. Primary comparative analysis of the $16 \mathrm{~S}$ rDNA sequence of strain ALEN $1^{\mathrm{T}}$ with sequences within the databases was done using BLAST. On the basis of the results of the BLAST search, the 16S rDNA sequences of strain ALEN $1^{\mathrm{T}}$ and its closest relatives were aligned by using CLUSTAL X (Thompson et al., 1994). Regions that were not sequenced in one or more of the reference organisms were omitted from subsequent analyses. An unrooted phylogenetic tree, based on the 16S rDNA sequences of the studied bacteria, was constructed by the neighbour-joining method available in the TREECON package (Van de Peer \& De Wachter, 1994). Additional phylogenetic trees were constructed by the maximum-likelihood method using the program PUZZLE (Strimmer \& von Haeseler, 1996), by the maximum-parsimony method using DNAPARS within the PHYLIP package (Felsenstein, 1989) and by the maximumtopological-similarity method using TREE within the GENEBEE package (http://www.genebee.msu.su). Bootstrap analysis (100 replications) was used to validate the reproducibility of the branching patterns of the trees.

\section{RESULTS AND DISCUSSION}

\section{Isolation of pure culture}

To test for anaerobic thiosulfate oxidation in the presence of nitrate at $\mathrm{pH} \mathrm{10,} \mathrm{as} \mathrm{indicated} \mathrm{by} \mathrm{Imhoff} \mathrm{et}$ al. (1979), enrichment cultures were inoculated with sediment samples from the eight largest hypersaline and alkaline lakes of the Wadi Natrun area, Libyan Desert, Egypt. Only an enrichment culture from lake Fazda showed reproducible growth. After several transfers, a stable mixed population developed that consisted of three distinct bacterial morphotypes barrel-like sulfur-containing non-motile rods, tiny thin motile rods and thin motile spirilla. Attempts to separate these different morphotypes by dilution series and plating led to the isolation of a spiral-shaped organism, which was thought to be responsible for the reduction of nitrate to nitrite in the mixed culture. This strain was designated ALEN $1^{\mathrm{T}}$.

\section{Morphology}

When grown in an argon atmosphere on thiosulfate/ nitrate alkaline agar, colonies of strain ALEN $1^{\mathrm{T}}$ were up to $2 \mathrm{~mm}$ in diameter, circular and flat, with a mosaic, skin-like surface and slimy consistency. The cells were fine, motile spirilla that were $0.3-0.45 \times 1-$ $4 \mu \mathrm{m}$ (occasionally up to $15 \mu \mathrm{m}$ in length) with a single polar flagellum (Fig. 1a, b). The cell ultrastructure was typical for Gram-negative bacteria (Fig. 1c-e). Cells contained globules of sulfur (Fig. 1a, c) and large, polar, electron-dense granules, which were presumed to be polyphosphates (Fig. 1d). Carboxysomal structures, as found in other haloalkaliphilic SOB (Sorokin et al., 2001a, 2002b), were absent. Cells of strain ALEN $1^{\mathrm{T}}$ stored at $4{ }^{\circ} \mathrm{C}$ or in the late growth phase showed rapid lysis; thin-sectioning of such cultures demonstrated various stages of cell lysis (Fig. 1e).

Cells of strain ALEN $1^{\mathrm{T}}$ harvested during the stationary phase contained a membrane-associated yellow pigment, which was readily extracted using an acetone/methanol mixture (7:3) and had an absorption maximum at $432 \mathrm{~nm}$. When transferred into hexane, the pigment had a broad maximum between 425 and $450 \mathrm{~nm}$ and a shoulder at $392 \mathrm{~nm}$. These characteristics are very similar to those of a pigment observed in extremely salt-tolerant strains belonging to the genus Thioalkalivibrio, which were isolated from hypersaline soda lakes in Mongolia, Kenya, Egypt and the USA (Sorokin et al., 2001a, 2002b; D. Yu. Sorokin, unpublished data). 

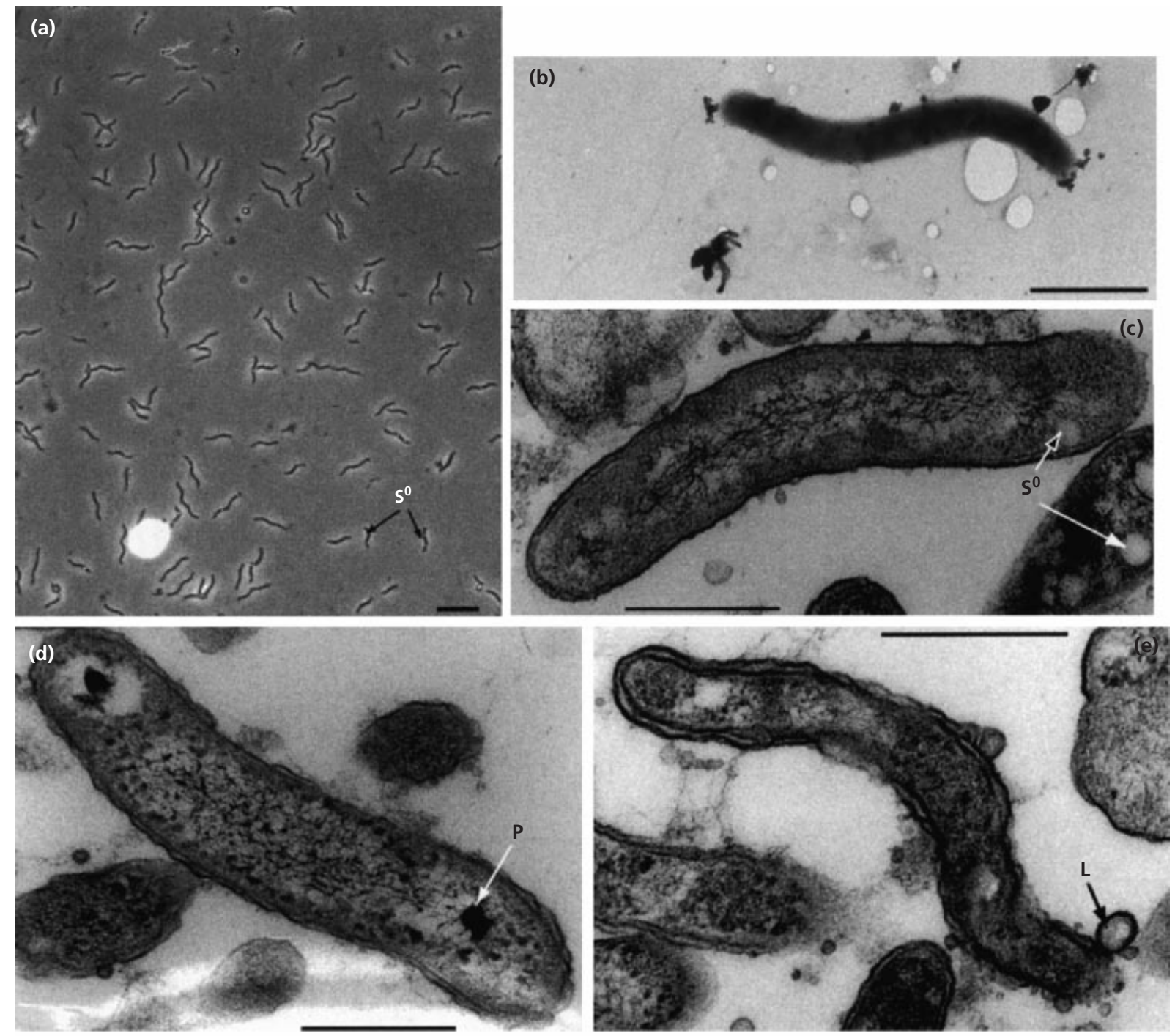

Fig. 1. Morphology of strain ALEN $1^{\top}$ when grown at $\mathrm{pH} 10$ with thiosulfate. (a) Phase-contrast micrograph (bar, $\left.10 \mu \mathrm{m}\right)$; (b) total preparation (bar, $1 \mu \mathrm{m})$; (c-e) thin-sections (bars, $0.5 \mu \mathrm{m}) . \mathrm{S}^{0}$, sulfur deposit; $\mathrm{P}$, polyphosphate granule; $L$, cell lysis.

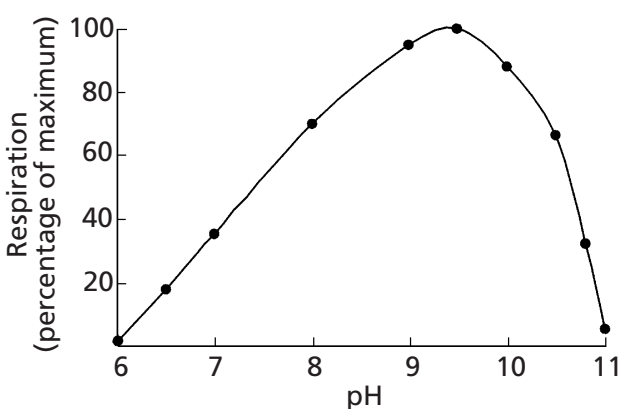

Fig. 2. Influence of $\mathrm{pH}$ on thiosulfate-dependent respiratory activity of washed cells of strain ALEN $1^{\top}$. All buffers contained $0.6 \mathrm{M}$ total $\mathrm{Na}^{+} ; 100 \%$ activity $=310 \mathrm{nmol} \mathrm{O}_{2}$ consumed (mg protein $)^{-1} \min ^{-1}$.

\section{Growth physiology}

Strain ALEN $1^{\mathrm{T}}$ is an obligately chemolithoautotrophic, sulfur-oxidizing bacterium. It can grow with thiosulfate and sulfide (in a sulfide-limited chemostat) as electron donors, but can not grow on media without reduced sulfur compounds in the presence of various organic compounds, $\mathrm{C}_{1}$ compounds or hydrogen. Ammonium salts (at concentrations of $<5 \mathrm{mM}$ ), nitrate and nitrite are used as nitrogen sources by strain ALEN $1^{\mathrm{T}}$ during its growth with thiosulfate at $\mathrm{pH} 10$. During microaerobic growth of the strain with thiosulfate, up to $95 \%$ of the thiosulfate sulfur was converted to sulfate with transient accumulation of up to $5 \mathrm{mM}$ of the cellassociated elemental sulfur. No other sulfur-containing 
Table 1. Respiration rates of washed cells of strain ALEN $1^{\top}$ at $\mathrm{pH} 10$ and $0.6 \mathrm{M}$ total $\mathrm{Na}^{+}$

Data shown are from two to three independent measurements. The stoichiometry of oxygen consumption with all of the substrates tested corresponds to their complete oxidation to sulfate.

\begin{tabular}{|lcc|}
\hline Substrate & \multicolumn{2}{c|}{$\begin{array}{c}\text { Rate of respiration (endogenous) } \\
\text { [nmol } \mathbf{O}_{\mathbf{2}} \text { consumed (mg protein) }\end{array}$} \\
& $\begin{array}{c}\text { Cells } \text { min }^{-\mathbf{1}} \text { ] } \\
\text { crom batch }\end{array}$ \\
\cline { 2 - 3 } & & $\begin{array}{c}\text { Cells from } \\
\text { continuous culture }\end{array}$ \\
\hline Sulfide $\left(\mathrm{HS}^{-}\right)$ & 370 & 300 \\
Polysulfide $\left(\mathrm{S}_{8}^{2-}\right)$ & 270 & 720 \\
Sulfur $\left(\mathrm{S}_{8}\right)$ & 90 & 65 \\
Thiosulfate $\left(\mathrm{S}_{2} \mathrm{O}_{3}^{2-}\right)$ & 310 & 210 \\
Tetrathionate $\left(\mathrm{S}_{4} \mathrm{O}_{6}^{2-}\right)$ & 40 & 45 \\
Sulfite $\left(\mathrm{SO}_{3}^{2-}\right)$ & 0 & 0 \\
\hline
\end{tabular}

Table 2. Enzyme activities in fractions of the cell-free extract of strain ALEN $1^{\top}$ grown with thiosulfate at $\mathrm{pH} 10$

\begin{tabular}{|c|c|c|c|}
\hline \multirow[t]{2}{*}{ Enzyme } & \multirow[t]{2}{*}{ Buffer, pH } & \multicolumn{2}{|c|}{$\begin{array}{c}\text { Activity [nmol (mg } \\
\text { protein) }{ }^{-1} \text { min }^{-1} \text { ] in fraction }\end{array}$} \\
\hline & & Soluble & Membrane \\
\hline Rhodanase & Carbonate, $8 \cdot 5$ & 170 & ND \\
\hline Thiosulfate reductase & Carbonate, $8 \cdot 5$ & 250 & ND \\
\hline Thiosulfate reductase & Carbonate, $10 \cdot 0$ & 880 & \\
\hline Thiosulfate cytochrome $c$ oxidoreductase & Carbonate, $8-10$ & 0 & 0 \\
\hline Sulfide dehydrogenase (cytochrome- $c$-dependent) & Carbonate, $10 \cdot 0$ & 110 & 31 \\
\hline Sulfite dehydrogenase (ferricyanide-dependent) & Carbonate, $8 \cdot 5$ & 40 & 0 \\
\hline Sulfite dehydrogenase (ferricyanide-dependent) & Carbonate, $10 \cdot 0$ & 160 & 0 \\
\hline Cytochrome $c$ oxidase & Carbonate, $8 \cdot 5$ & & 2300 \\
\hline Cytochrome $c$ oxidase & Carbonate, $10 \cdot 0$ & ND & 860 \\
\hline Catalase & Tris $/ \mathrm{HCl}, 8 \cdot 0$ & 16000 & ND \\
\hline
\end{tabular}

ND, Not determined.

intermediates have been detected. Despite rapid re-utilization of the intracellular sulfur by thiosulfategrown cultures, strain ALEN $1^{\mathrm{T}}$ was unable to initiate growth when external crystalline sulfur was used as a substrate.

Despite the fact that it was isolated from an anoxic enrichment, strain ALEN $1^{\mathrm{T}}$ is an obligate aerobe that requires micro-oxic conditions. Successful batch cultivation of the organism was achieved in a gas atmosphere containing $1-2 \% \quad \mathrm{O}_{2}$, whereas in the presence of higher concentrations of oxygen $(>2 \%$ $\mathrm{O}_{2}$ ) growth was observed only when a massive inoculum was used, due to the immediate oxygen depletion in the liquid phase. Actively growing cultures of strain ALEN $1^{\mathrm{T}}$ allowed successive incubations on a rotary shaker; tests, using an oxygen electrode, showed there to be $<10 \%$ dissolved oxygen in these cultures. As soon as the oxygen concentration in the liquid phase of the cultures went above $10 \%$, heavy sulfur formation was observed, which was followed by complete inhibition of growth. The same phenomenon was observed in dense, rapidly growing cultures of strain ALEN $1^{\mathrm{T}}$, where the concentration of dissolved oxygen in the medium was not enough for complete oxidation of thiosulfate to sulfate. In thiosulfatelimited continuous cultures of strain ALEN $1^{\mathrm{T}}$ at pH 10 and $0.6 \mathrm{M}$ total $\mathrm{Na}^{+}$with $5 \mathrm{mM}$ nitrate as nitrogen source, stable growth of the strain was achieved at a $\mathrm{pO}_{2}$ concentration of $<10 \%$ air saturation. The maximal specific growth rate and yield of the strain were $0.08 \mathrm{~h}^{-1}$ and $5.9 \mathrm{mg}$ protein $\mathrm{mmol}^{-1}$, respectively.

Strain ALEN $1^{\mathrm{T}}$ was able to reduce up to $20 \mathrm{mM}$ nitrate to nitrite during micro-oxic growth with $40 \mathrm{mM}$ thiosulfate, but nitrate did not support anaerobic growth of the organism. The physiological role of nitrate reduction remains unclear. Since the nitrate reductase activity of strain ALEN $1^{\mathrm{T}}$ is inhibited by oxygen but not ammonia, the enzyme has to be of a dissimilatory type. Perhaps the reaction serves as a 


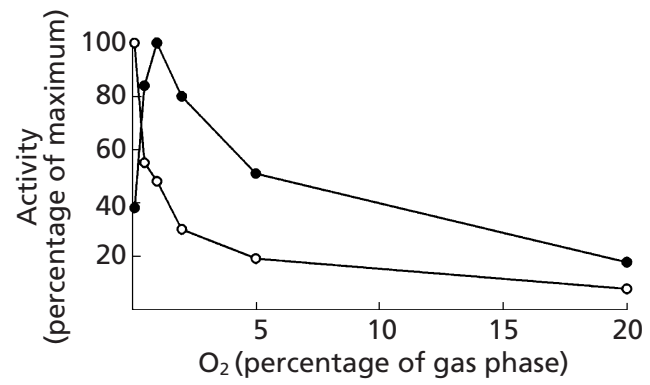

Fig. 3. Impact of oxygen content on the activity of inorganic carbon fixation by washed cells of strain ALEN $1^{\top}$ at $\mathrm{pH} 9$ and $0.6 \mathrm{M} \mathrm{NaCl}$ in the presence of $5 \mathrm{mM}$ thiosulfate. $\bigcirc$, Cell density $0.05 \mathrm{mg}$ protein $\mathrm{ml}^{-1} ; 0$, cell density $0.15 \mathrm{mg}^{\circ}$ protein $\mathrm{ml}^{-1}$.

sink for excessive reducing equivalents during microoxic growth? The maximum nitrate reductase activity in the cell-free extract of strain ALEN $1^{\mathrm{T}}$ at $\mathrm{pH} 8$ with reduced methyl viologen was $70 \mathrm{nmol} \mathrm{NO}_{2}^{-}$released (mg protein $)^{-1} \mathrm{~min}^{-1}$, while nitrite reductase activity was undetectable. $\mathrm{N}_{2} \mathrm{O}$ was not used as an electron acceptor. During the anaerobic incubation of washed cells of strain ALEN $1^{\mathrm{T}}$, apart from nitrate reduction, which was stimulated by thiosulfate, sulfide or polysulfide, the reduction of elemental sulfur was observed, with a maximum activity of $7 \cdot 2 \mathrm{nmol}$ sulfane released (mg protein $)^{-1} \mathrm{~min}^{-1}$. Since neither hydrogen nor thiosulfate stimulated sulfur reduction or allowed growth of the organism, it may be concluded that strain ALEN $1^{\mathrm{T}}$ can use sulfur reduction as an electron sink.

\section{Influence of $\mathrm{pH}$ and salts on growth and activity}

Strain ALEN $1^{\mathrm{T}}$ can be considered to be a moderately haloalkaliphilic bacterium. In media containing $0.6 \mathrm{M}$ total $\mathrm{Na}^{+}$, it was able to grow at $\mathrm{pH} 8-10 \cdot 4$ (final $\mathrm{pH}$ values) with optimum growth observed at $\mathrm{pH} 9 \cdot 5-10 \cdot 0$. At $\mathrm{pH} 10$, strain ALEN $1^{\mathrm{T}}$ tolerated up to $1.4 \mathrm{M} \mathrm{Na}^{+}$ from sodium carbonate/bicarbonate, and had a minimal $\mathrm{Na}^{+}$requirement of $0 \cdot 2 \mathrm{M}$; optimum growth was observed at $0.5 \mathrm{M} \mathrm{Na}^{+}$at $\mathrm{pH} 10$. Washed cells of strain ALEN $1^{\mathrm{T}}$ grown in a chemostat at $\mathrm{pH} 10$ with $0.6 \mathrm{M} \mathrm{Na}^{+}$were able to respire with thiosulfate within a broad $\mathrm{pH}$ range (pH 6.5-10.8) with optimum activity at $\mathrm{pH} 9 \cdot 5$ (Fig. 2).

\section{Activity of oxidation of inorganic sulfur compounds, sulfur-metabolizing enzymes and cytochrome composition}

Washed cells of strain ALEN $1^{\mathrm{T}}$ grown with thiosulfate in batch culture had relatively high and almost equal respiration with thiosulfate, sulfide and polysulfide, whereas the oxidation of elemental sulfur or tetrathionate by washed cells of the strain was substantially slower (Table 1). Surprisingly, polysulfide was the best substrate for cells of strain ALEN $1^{\mathrm{T}}$ when they were grown in a thiosulfate-limited chemostat under micro-

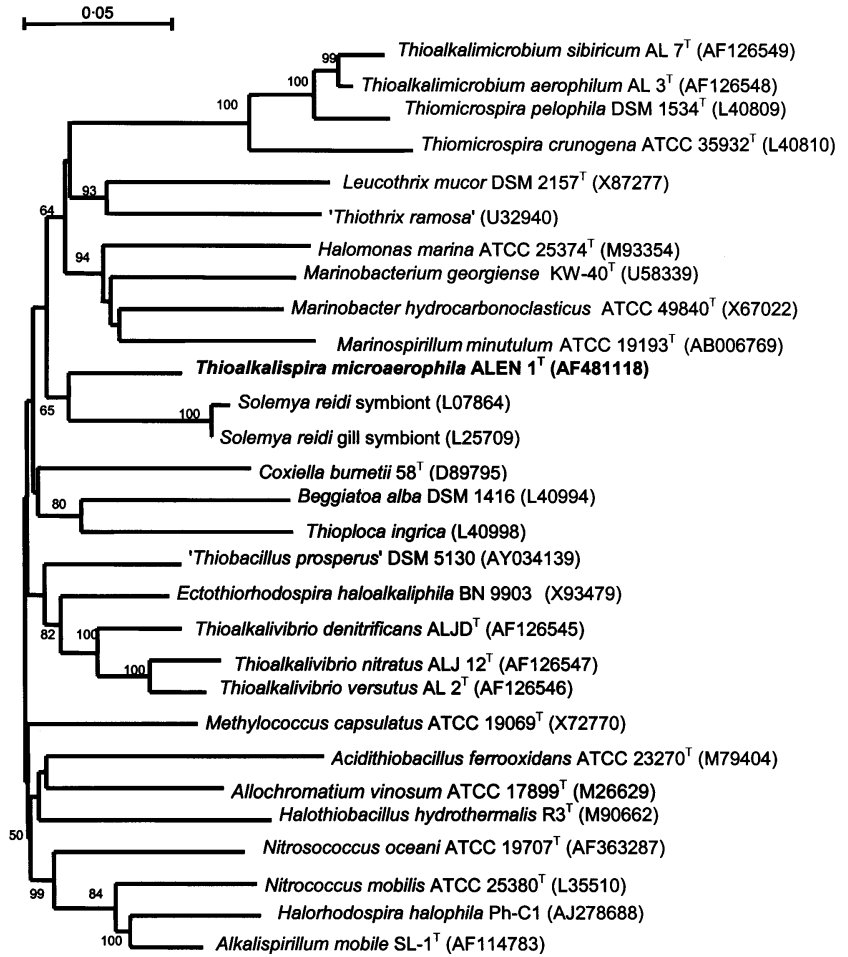

Fig. 4. Phylogenetic tree demonstrating the position of strain ALEN $1^{\top}$ within the $\gamma$-Proteobacteria. Bootstrap values (expressed as a percentage of 100 replications) are shown at branch points, and only values $>50 \%$ are included; values $>90 \%$ were considered significant. Bar, 5 substitutions per 100 nucleotides.

oxic conditions. The $K_{\mathrm{s}}$ value for thiosulfate, as determined for chemostat-grown cells of strain ALEN $1^{\mathrm{T}}$, was $4 \cdot 5 \pm 1 \mu \mathrm{M}$ (mean of three measurements $\pm \mathrm{SD}$ ). The stoichiometry of oxygen consumption with all of the substrates tested suggested that sulfate was formed as the end product of sulfur oxidation by strain ALEN $1^{\mathrm{T}}$.

Among all of the enzymes that were possibly involved in sulfur oxidation, the thiosulfate reductase of strain ALEN $1^{\mathrm{T}}$ was the most active (Table 2). In contrast to other haloalkaliphilic SOB (Sorokin et al., 1998), the sulfide dehydrogenase activity of strain ALEN $1^{\mathrm{T}}$ was located mostly in the soluble fraction. The complete absence of any tetrathionate synthase activity (thiosulfate-dependent ferricyanide reduction), together with very low activity for tetrathionate oxidation by washed cells of strain ALEN $1^{\mathrm{T}}$, suggest that tetrathionate is not an important intermediate during the oxidation of thiosulfate by this novel bacterium. Overall, the respiratory and enzymic profiles determined here suggest that in strain ALEN $1^{\mathrm{T}}$ sulfide is oxidized via polysulfide and elemental sulfur to sulfate.

Cells of strain ALEN $1^{\mathrm{T}}$ contained high amounts of cytochromes, as indicated by the colour of their membranes and the soluble fraction. Spectral analysis of the soluble fraction and the membranes demon- 
strated the presence of a fully developed cytochrome chain within strain ALEN $1^{\mathrm{T}}$ (data not shown). The soluble fraction contained two different cytochromes of the cytochrome $c$ reducible with ascorbate $\left(c_{551}\right)$ or dithionite $\left(c_{553}\right)$. The spectra of the membranes suggested the presence of cytochromes of $c_{553}$ and $b_{559}$, and a $c b$-type CO-binding oxidase within strain ALEN $1^{\mathrm{T}}$.

\section{Nature of the microaerophily of strain ALEN $1^{\top}$}

Surprisingly, strain ALEN $1^{\mathrm{T}}$ had very high cytochrome $c$ oxidase and catalase activites (Table 2) usually these enzymes are found at low levels in microaerophiles. Therefore, another possible explanation for the dependence of this strain on micro-oxic growth conditions might be that it possesses an oxygen-sensitive form II RuBisCO, like many other chemolithoautotrophic bacteria (Tabita, 1995; Igarashi \& Kodama, 1995; Grabovich et al., 2001; Götz et al., 2002).

In washed cells of strain ALEN $1^{\mathrm{T}}$, the inorganic carbon fixation activity of this bacterium was indeed strongly inhibited at oxygen concentrations of between 2 and $5 \%$ in the gas phase, depending on the cell density (e.g. oxygen consumption activity; Fig. 3). Therefore, it can be concluded that the sensitivity of the carbon fixation pathway is at least one of the important reasons for microaerophily in this chemolithoautotrophic haloalkaliphile.

\section{Genetic and phylogenetic analyses}

The DNA $\mathrm{G}+\mathrm{C}$ content of strain ALEN $1^{\mathrm{T}}$ was $58.9 \pm 0.5 \mathrm{~mol} \%\left(T_{\mathrm{m}}\right)$, which is lower than the values observed for all of the known haloalkaliphilic SOB of the genera Thioalkalimicrobium and Thioalkalivibrio isolated so far (Sorokin et al., 2001a, 2002a, b). The levels of DNA-DNA hybridization between strain ALEN $1^{\mathrm{T}}$ and the type strains of these genera did not exceed non-specific background values, which indicated that strain ALEN $1^{\mathrm{T}}$ was not closely related to any previously described haloalkaliphilic SOB and, therefore, represented a novel genus.

According to a comparison of its $16 \mathrm{~S}$ rDNA sequence with those available from GenBank, strain ALEN $1^{\text {T }}$ was a member of the $\gamma$-Proteobacteria, displaying highest sequence similarity $(\sim 90 \%)$ to 'Thiobacillus prosperus' DSM 5130 and an unidentified marine $\gamma$ Proteobacteria strain, BD3-1 (AB015547). Among the validly published bacterial species, the closest neighbour of strain ALEN $1^{\mathrm{T}}$ was Marinobacter aquaeolei ( $89 \%$ sequence similarity). However, in the phylogenetic trees that were constructed in this study (an example is given in Fig. 4), strain ALEN $1^{\mathrm{T}}$ clustered neither with the aforementioned 'related' organisms nor with any other described representatives of the $\gamma$ Proteobacteria. Instead, strain ALEN $1^{\mathrm{T}}$ formed a distinct lineage within a cluster containing two sequences from symbiotic bacteria of Solemya reidi
(L07864) and of Solemya reidi gill (L25709). The levels of sequence similarity between strain ALEN $1^{\mathrm{T}}$ and the symbiotic bacteria were between 91.6 and $92.7 \%$ in all of the trees constructed by the different methods used in this study, with the highest bootstrap probability $(0.95)$ of this branching point seen in a tree constructed using the maximum-parsimony method (data not shown). The phylogenetic position of the branch containing strain ALEN $1^{\mathrm{T}}$ was unstable, and was dependent on the selection of the reference organisms and the treeing algorithm used. On the basis of our phylogenetic analyses it can be concluded that strain ALEN $1^{\mathrm{T}}$ represents a novel, deep branch within the $\gamma$ Proteobacteria whose true phylogenetic position can be identified only when more similar sequences are available for comparison.

In conclusion, on the basis of its unique phenotypic properties and distinct phylogenetic position, it is proposed that the novel haloalkaliphilic, obligately chemolithoautotrophic SOB strain described here, ALEN $1^{\mathrm{T}}$, be assigned to a novel genus, Thioalkalispira, and species, Thioalkalispira microaerophila.

\section{Description of Thioalkalispira gen. nov.}

Thioalkalispira (Thi.o.al.kal.i.spi'ra. Gr. n. thios sulfur; N.L. n. alkali from Arabic al qaliy the soda ash; Gr. n. spira spiral; N.L. fem. n. Thioalkalispira sulfur alkaline spiral).

Characteristics are the same as those given for the type species of the genus, Thioalkalispira microaerophila, which is represented by a single strain.

\section{Description of Thioalkalispira microaerophila sp. nov.}

Thioalkalispira microaerophila (mic.ro.aer.oph.i'la. Gr. adj. micros small, little; Gr. masc. n. aër gas; Gr. adj. philos loving; N.L. fem. adj. microaerophila lowair-loving).

Obligately chemolithoautotrophic. Cells have a Spirillum-like morphology, with dimensions 0.3$0 \cdot 45 \times 1-4 \mu \mathrm{m}$ (occasionally up to $15 \mu \mathrm{m}$ in length). Motile by means of a single polar flagellum. Gramnegative cell wall. Deposits intracellular sulfur globules and polar polyphosphate granules. Oxidizes sulfide, polysulfide, elemental sulfur and thiosulfate to sulfate. Obligate aerobe and microaerophile, able to grow only under reduced oxygen concentrations $(<2 \%)$. Nitrate and sulfur are reduced to nitrite and sulfide, respectively, without growth. Alkaliphilic, with the $\mathrm{pH}$ range for growth between 8 and 10.4 (optimum around $\mathrm{pH}$ 10). Moderately halophilic, with total $\mathrm{Na}^{+}$content suitable for growth between $0 \cdot 2$ and $1.4 \mathrm{M}$ (optimum $0.5 \mathrm{M})$. DNA $\mathrm{G}+\mathrm{C}$ content is $58.9 \mathrm{~mol} \%\left(T_{\mathrm{m}}\right)$. Isolated from hypersaline alkaline lake Fazda (Wadi Natrun, Egypt). The type strain of Thioalkalispira microaerophila is ALEN $1^{\mathrm{T}} \quad\left(=\mathrm{DSM} 14786^{\mathrm{T}}=\right.$ UNICEM $212^{\mathrm{T}}$ ). 


\section{ACKNOWLEDGEMENTS}

This work was supported by RFBR (grant no. 01-04-48782). We would like to thank M. Moussa for help in obtaining samples from the Wadi Natrun Lakes and B. Tindall for helping with the deposition of strain ALEN $1^{\mathrm{T}}$ in the DSMZ (Deutsche Sammlung von Mikroorganismen und Zellkulturen, Mascheroder Weg 1B, D-38124 Braunschweig, Germany).

\section{REFERENCES}

De Ley, J., Cattoir, H. \& Reynaerts, A. (1970). The quantitative measurement of DNA hybridization from renaturation rates. Eur $J$ Biochem 12, 133-142.

Felsenstein, J. (1989). PHYLIP - Phylogeny inference package (version 3.2). Cladistics 5, 164-166

Götz, D., Banta, A., Beveridge, T. J., Rushdi, A. I., Simoneit, B. R. T. \& Reysenbach, A.-L. (2002). Persephonella marina gen. nov., sp. nov. and Persephonella guaymasensis sp. nov., two novel, thermophilic hydrogen-oxidizing microaerophiles from deep-sea hydrothermal vents. Int J Syst Evol Microbiol 52, 1349-1359.

Grabovich, M. Yu., Patritskaya, V. Yu., Muntyan, M.S. \& Dubinina, G. A. (2001). Lithoautotrophic growth of Beggiatoa D-402 and energy conservation in a homogenous culture under microoxic conditions. FEMS Microbiol Lett 204, 341-345.

Igarashi, Y. \& Kodama, T. (1995). Genes related to carbon dioxide fixation in Hydrogenovibrio marinus and Pseudomonas hydrogenothermophila. In Microbial Growth on $C_{1}$ Compounds, pp. 88-93. Edited by M. E. Lidstrom \& F. R. Tabita. Dordrecht: Kluywer.

Imhoff, J. F., Sahl, H. G., Soliman, G. S. H. \& Trüper, H. G. (1979). The Wadi Natrun: chemical composition and microbial mass developments in alkaline brines of eutrophic desert lakes. Geomicrobiol $J \mathbf{1}$, 219-234.

Jørgensen, B. B. (1989). Biogeochemistry of chemolithoautotrophic bacteria. In Autotrophic Bacteria, pp. 117-146. Edited by H. G. Schlegel \& B. Bowien. Berlin: Springer.

Kelly, D. P. (1989). Physiology and biochemistry of unicellular sulfur bacteria. In Autotrophic Bacteria, pp. 193-217. Edited by H. G. Schlege \& B. Bowien. Berlin: Springer.

Kuenen, J. G., Robertson, L. A. \& Tuovinen, O. H. (1992). The genera Thiobacillus, Thiomicrospira and Thiosphaera. In The Prokaryotes, 2nd edn. pp. 2638-2657. Edited by A. Balows, H. G. Trüper, M. Dworkin, W. Harder \& K.-H. Schleifer. Berlin: Springer.

Marmur, J. (1961). A procedure for isolation of DNA from microorganisms. J Mol Biol 3, 208-214.

Martinez Murillo, F., Gugliuzza, T., Senko, J., Basu, P. \& Stolz, J. (1999). A heme-C-containing enzyme complex that exhibits nitrate and nitrite reductase activity from the dissimilatory iron-reducing bacterium Geobacter metallireducens. Arch Microbiol 172, 313-320.

Pronk, J. T., Meulenberg, R., Hazeu, W., Bos, P. \& Kuenen, J. G. (1990). Oxidation of reduced inorganic sulfur compounds by acidophilic thiobacilli. FEMS Microbiol Rev 75, 293-306.
Robertson, L. A. \& Kuenen, J. G. (1992). The use of natural bacterial populations for the treatment of sulfur-containing wastewater. Biodegradation 3, 239-254.

Sorokin, D. Yu., Lysenko, A. M. \& Mityushina, L. L. (1996). Isolation and characterisation of alkaliphilic heterotrophic bacteria capable of oxidation of inorganic sulfur compounds to tetrathionate. Microbiology (English translation of Mikrobiologiya) 65, 326-338.

Sorokin, D., Yu., de Jong, G. A., Robertson, L. A. \& Kuenen, J. G. (1998). Purification and characterization of sulfide dehydrogenase from alkaliphilic chemolithoautotrophic sulfur-oxidizing bacteria. FEBS Lett 427, 11-14.

Sorokin, D. Yu., Robertson, L. A. \& Kuenen, J. G. (2000). Isolation and characterisation of obligately chemolithoautotrophic alkaliphilic sulfur-oxidizing bacteria. Antonie van Leeuwenhoek 77, 251-260.

Sorokin, D. Yu., Lysenko, A. M., Mityushina, L. L., Tourova, T. P., Jones, B. E., Rainey, F. A., Robertson, L. A. \& Kuenen, J. G. (2001a). Thioalkalimicrobium aerophilum gen. nov., sp. nov. and Thioalkalimicrobium sibericum sp. nov., and Thioalkalivibrio versutus gen. nov., sp. nov., Thioalkalivibrio nitratis sp. nov., novel and Thioalkalivibrio denitrificans sp. nov., novel obligately alkaliphilic and obligately chemolithoautotrophic sulfur-oxidizing bacteria from soda lakes. Int $J$ Syst Evol Microbiol 51, 565-580.

Sorokin, D. Yu., Kuenen, J. G. \& Jetten, M. (2001b). Denitrification at extremely high $\mathrm{pH}$ values by the alkaliphilic, obligately chemolithoautotrophic, sulfur-oxidizing bacterium Thioalkalivibrio denitrificans strain ALJD. Arch Microbiol 175, 94-101.

Sorokin, D. Yu., Gorlenko, V. M., Tourova, T. P., Kolganova, T. V., Tsapin, A. I., Nealson, K. H. \& Kuenen, J. G. (2002a). Thioalkalimicrobium cyclicum sp. nov. and Thioalkalivibrio jannaschii sp. nov., novel species of haloalkaliphilic, obligately chemolithoautotrophic sulfur-oxidizing bacteria from hypersaline alkaline Mono Lake (California). Int J Syst Evol Microbiol 52, 913-920.

Sorokin, D. Yu., Tourova, T. P., Lysenko, A. M., Mityushina, L. L. \& Kuenen, J. G. (2002b). Thioalkalivibrio thiocyanoxidans sp. nov. and Thioalkalivibrio paradoxus sp. nov., novel alkaliphilic, obligately autotrophic, sulfur-oxidizing bacteria capable of growth on thiocyanate, from soda lakes. Int J Syst Evol Microbiol 52, 657-664.

Strimmer, K. \& von Haeseler, A. (1996). Quartet puzzling: a quartet maximum likelihood method for reconstructing tree topologies. $\mathrm{Mol}$ Biol Evol 13, 964-969.

Sumner, J. B. \& Dounce, A. L. (1955). Liver catalase. Methods Enzymol 2, 780

Tabita, F. R. (1995). The biochemistry and metabolic regulation of carbon metabolism and $\mathrm{CO}_{2}$ fixation in purple bacteria. In Anoxygenic Photosynthetic Bacteria, pp. 885-914. Edited by R. E. Blankenship, M. T. Madigan \& C. E. Bauer. Dordrecht: Kluwer.

Thompson, J. D., Higgins, D. G. \& Gibson, T. J. (1994). CLUSTAL W: improving the sensitivity of progressive multiple sequence alignment through sequence weighting, position-specific gap penalties and weight matrix choice. Nucleic Acids Res 22, 4673-4680.

Van de Peer, Y. \& De Wachter, R. (1994). TREECON for Windows: a software package for the construction and drawing of evolutionary trees for the Microsoft Windows environment. Comput Appl Biosci 10, $569-570$. 